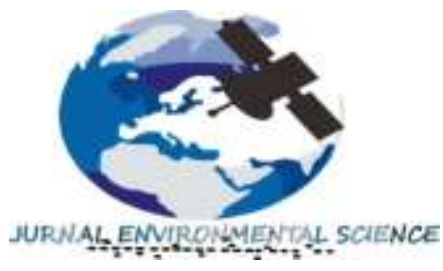

Jurnal Environmental Science

Volume 3 Nomor 2 April 2021

p-ISSN : 2654-4490 dan e-ISSN : 2654-9085

Homepage at : ojs.unm.ac.id/JES

E-mail:jes@unm.ac.id

\title{
PEMETAAN ZONASI DAERAH RAWAN BENCANA LONGSOR BERBASIS SISTEM INFORMASI GEOGRAFI DI DAS JENEBERANG KABUPATEN GOWA
}

\author{
Muh. Rizal Darwis ${ }^{(1)}$ Uca $^{(2}$ Muhammad Yusuf ${ }^{(3)}$ \\ Jurusan Geografi, Fakultas Matematika dan Ilmu Pengetahuan Alam \\ Universitas Negeri Makassar, Indonesia \\ Email: muh.risal3098@gmail.com
}

\begin{abstract}
ABSTRAK
Bencana longsor di Indonesia bisa dijumpai hampir di setiap Daerah Aliran Sungai utamanya pada bagian hulu Daerah Aliran Sungai. Salah satu penyebab terjadinya longsor yaitu kondisi topografi yang sangat curam. Salah satu Daerah Aliran Sungai di Sulawesi Selatan yang memiliki peran penting dan strategis dalam pembangunan adalah Daerah Aliran Sungai Jeneberang. Penelitian ini bertujuan untuk mengetahui tingkat kerawanan dan sebaran daerah yang berpotensi longsor di DAS. Jenis penelitian ini merupakan penelitian deskriptif kuantitatif dengan prosedur analisis software Geographic Information System (GIS) berupa analisis tumpang tindih (overlay) faktor-faktor yang berpengaruh terhadap kejadian tanah longsor seperti Jenis batuan, kemiringan lereng, curah hujan, zona kerentanan gerakan tanah, tekstur tanah dan tutupan lahan. Berdasarkan hasil pendugaan kerawanan longsor di DAS Jeneberang, diperoleh tiga tingkat kerawanan longsor yaitu: Tingkat kerawanan rendah dengan luas 30771 Ha (39\%) memiliki persebaran di Kecamatan Bontomaranu, Palangga, Bajeng Barombong, Tamalate, dan lain-lain, Tingkat kerawanan sedang dengan luas 38827 Ha (49\%) memiliki persebaran di Kecamatan Parangloe, Manuju, Bungaya, Tinggimoncong dan Parigi. Dan tingkat kerawanan tinggi dengan luas 9287 Ha (12\%) memiliki persebaran di Kecamatan Tinggimoncong, Parigi dan beberapa daerah di Kecamatan Parangloe dan Manuju.
\end{abstract}

Kata Kunci: Longsor, Daerah Aliran Sungai, Geographic Information System

\begin{abstract}
Landslides in Indonesia can be found in almost every watershed, especially in the upstream part of the watershed. One of the causes of landslides is the very steep topography. One of the watersheds in South Sulawesi that has an important and strategic role in development is the Jeneberang River Basin. This study aims to determine the level of vulnerability and the distribution of landslide potential areas in the watershed. This type of research is a quantitative descriptive study with Geographic Information System (GIS) software analysis procedures in the form of overlapping analysis (overlay) of factors that influence landslides such as rock type, slope, rainfall, soil movement vulnerability zones, soil texture. and land cover. Based on the results of the estimation of landslide vulnerability in the Jeneberang watershed, three levels of landslide vulnerability were obtained, namely: Low hazard levels with an area of 30771 hectares (39\%) having a distribution in the Districts of Bontomaranu, Palangga, Bajeng Barombong, Tamalate, and others. $38827 \mathrm{Ha}(49 \%)$ has a distribution in Parangloe, Manuju, Bungaya, Tinggimoncong and Parigi Districts. And the high level of vulnerability with an area of 9287 hectares (12\%) has the distribution in Tinggimoncong, Parigi and several areas in Parangloe and Manuju Districts.
\end{abstract}

Keywords: Landslides, Watershed, Geographic Information System. 


\section{PENDAHULUAN}

Di Indonesia bencana alam berupa longsor bisa dijumpai hampir di setiap Daerah Aliran Sungai (DAS) utamanya pada bagian hulu DAS. Salah satu penyebab terjadinya longsor yaitu kondisi topografi yang sangat curam (Arsyad, 2012). Keadaan ini sesuai dengan keadaan hulu DAS yang memiliki kemiringan lereng yang sangat curam (Indarto, 2010). Hal tersebut juga diperparah oleh aktivitas manusia yang berada di dalam DAS. Aktivitas manusia seperti pengembangan permukiman, perindustrian, pemekaran wilayah administrasi, alih fungsi kawasan hutan dapat meningkatkan lahan terbuka, ketidakstabilan lereng dan vegetasi semakin berkurang serta rendahnya penerapan teknik konservasi tanah dan air.

Kerawanan terhadap bencana longsor akan menghambat pembangunan suatu wilayah. Bencana longsor yang terjadi dapat menimbulkan berbagai dampak dan kerugian yang cukup besar, terutama korban jiwa, kerusakan fasilitas umum dan kerugian materi lainnya. Menurut Triutomo (2010) dalam dalam buku Mitigasi Bencana (Disaster Mitigation) Nasiah dan Icshan (2016) menyatakan bahwa:

"Sebanyak 11 Kabupaten di Sulawesi Selatan dinyatakan oleh Badan Pengendalian Dampak Lingkungan Daerah (Bapedalda) Sulsel sebagai daerah rawan longsor pada musim penghujan adalah Enrekang, Tana Toraja, Palopo, Luwu Utara, Luwu Timur, Soppeng, Wajo, Sinjai, Jeneponto, Bantaeng dan Gowa. Daerah-daerah tersebut menjadi rawan karena hutan telah gundul. Akibat bencana itu, tidak sedikit rumah warga yang rusak, harta benda hilang, bahkan sudah banyak warga yang kehilangan nyawanya seperti yang pernah menimpa Sinjai, Gowa, Palopo, dan beberapa daerah lainnya di Sulsel"

Oleh Karena itu, Perencanaan pembangunan wilayah perlu memasukkan variabel potensi rawan longsor sebagai salah satu pertimbangan kelayakan fisik. Salah satu DAS yang memiliki peran penting dan strategis dalam pembangunan di Provinsi Sulawesi Selatan adalah DAS Jeneberang yang terdapat pada Kabupaten Gowa. DAS Jeneberang merupakan salah satu DAS prioritas Nasional sebagaimana yang tercantum dalam Surat Keputusan Bersama Menteri Dalam Negeri, Menteri Kehutanan dan Menteri Pekerjaan Umum Nomor 19 Tahun 1984, Nomor 059/Kpts-II/1985 dan Noomor 124/Kpts/1984 yang memerlukan perhatian khusus dalam pengelolaannya (Sylvani, 2010).

Dari hasil studi WALHI Sulsel, terungkap vegetasi DAS Jeneberang sekitar 83 persen adalah non-hutan dan sisanya sekitar 16 persen adalah hutan. Ada beberapa faktor yang mempengaruhi berkurangnya vegetasi di daerah DAS Jeneberang, penyebab utama adalah alih fungsi hutan menjadi kebun sayuran, permukiman, dan bangunan vila, ini banyak terjadi di bagian hulu DAS Jeneberang. Pertanian hortikultura seperti wortel, kentang, jagung, dan sayuran lain sedikit demi sedikit merambah masuk ke areal Gunung Bawakaraeng hingga di lereng-lereng terjal. Area lereng tempat tegakan pohon pun berganti menjadi kebun sayur tanpa menggunakan pola terasering. Keadaan ini diperparah dengan maraknya aktivitas pertambangan tak berizin di bagian tengah badan Jeneberang yang dapat mengurangi tingkat sedimentasi di sungai. Inilah yang disebut menjadi potensi besar terjadinya banjir dan tanah longsor di DAS Jeneberang.

Hal ini dibuktikan pada akhir bulan Januari tahun 2019 banyak bencana banjir dan tanah longsor yang terjadi di sekitar DAS Jeneberang Kabupaten Gowa, Longsor terjadi akibat hujan dalam intensitas tinggi yang mengguyur dalam beberapa hari belakangan. Titik longsor antara lain ada di Desa Lonjoboko di Kecamatan Parangloe, Desa Datara, Tompobulu, Bilanrengi, Desa Parigi, Desa Bili-bili di Kecamatan Bontomarannu yang mengakibatkan banyak rumah warga yang rusak, akses jalan terputus bahkan sampai menelan korban jiwa. Longsor yang paling parah menerjang Desa Pattallikang di Kecamatan Manuju yang menimbun satu dusun, yaitu dusun Pattiro.

Berdasarkan hal tersebut, maka perlu adanya sebuah upaya identifikasi daerah rawan bencana longsor agar dapat meminimalisir kerugian yang ditimbulkannya. Untuk itu, penulis mengambil judul "Pemetaan Zonasi Daerah Rawan Bencana Longsor Berbasis Sistem Informasi Geografi (SIG) di DAS Jeneberang Kabupaten Gowa".

\section{METODE}

Metode yang digunakan dalam penelitian ini adalah metode deskriptif kuantitatif dengan prosedur analisis software Geographic Information System (GIS) berupa analisis tumpang tindih (overlay) faktor-faktor yang berpengaruh terhadap kejadian tanah longsor. Penelitian deskriptif 
adalah penelitian yang berusaha untuk menggambarkan gejala, peristiwa atau kejadian yang terjadi sekarang. Dengan kata lain, menurut Nana Sudjana dan Ibrahim (2004:64)

Penelitian deskriptif dibedakan dari beberapa eksperimen, karena objek penelitian dibiarkan apa adanya, tanpa ada perlakuan khusus dari peneliti. Secara garis besar, penelitian ini dibagi menjadi tiga tahapan pelaksanaan yang terdiri dari, pengumpulan data, analisa data dan penarikan kesimpulan.

Hasil yang diperoleh berupa zonasi daerah rawan longsor di DAS Jeneberang, sehingga diharapkan dapat bermanfaat bagi pemerintah dan masyarakat dalam menanggulangi dan mengantisipasi adanya bahaya dari tanah longsor. Adapun variabel penelitian tersebut antara lain: Jenis Batuan, Kemiringan lereng, Curah hujan, Zona kerentanan gerakan tanah, Tekstur tanah dan Tutupan lahan.

\section{Lokasi Penelitian}

Lokasi penelitian adalah Daerah Aliran Sungai (DAS) Jeneberang yang terletak di Provinsi Sulawesi Selatan yang berada di Kabupaten Gowa. DAS ini memiliki luas sebesar 78.885 Ha.

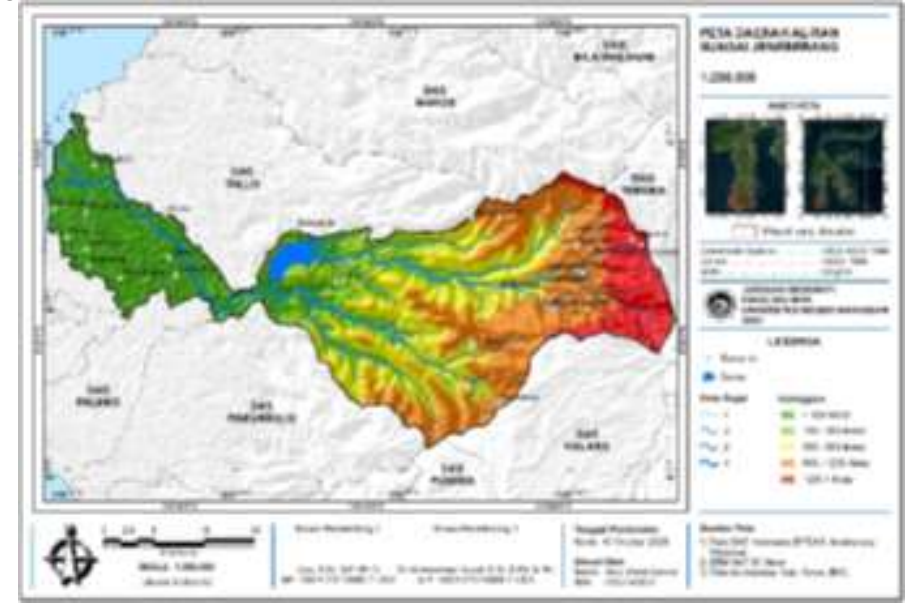

Gambar 1. Lokasi Penelitian

\section{Tahap Persiapan}

Melakukan kajian literatur untuk menunjang penelitian yang dilakukan, melakukan observasi untuk mengetahui kondisi di lokasi penelitian, mengurus surat izin penelitian dan mempersiapkan alat dan data sekunder yang dibutuhkan dalam tahap pembuatan peta.

\section{Tahap Pengumpulan Data}

Terdiri dari observasi dan dokumentasi. Observasi merupakan metode yang digunakan sebelum dan sesudah melakukan tinjauan lapangan, bertujuan agar hasil pemetaan data lapangan dapat akurat, karena metode ini sekaligus menjadi cara untuk menguji data yang di lapangan. Dan dokumentasi adalah Dokumentasi adalah teknik yang digunakan peneliti dalam mencari data mengenai hal-hal atau variabel yang berupa catatan transkrip, buku, majalah, surat kabar, prasasti, notulen rapat, dan lain sebagainya. Teknik dokumentasi dalam penelitian ini dilakukan untuk memperoleh hampir semua data yang diperlukan. Jenis data yang diperlukan dalam penelitian ini adalah data sekunder yang diperoleh dari berbagai instansi, dinas atau lembaga yang terkait dalam penelitian ini.

\section{Teknik Pengambilan Sampel Tanah}

Titik sampel untuk pengambilan sampel tanah dilakukan dengan cara overlay peta jenis tanah dan peta kemiringan lereng. Hasil overlay dua peta tersebut berjumlah 19 satuan lahan yang kemudian digunakan untuk pengambilan sampel tanah untuk analisis tekstur tanah. Adapun teknik pengambilan sampel yang digunakan yaitu purposive sampling. Pengambilan sampel pada setiap jenis tanah dilakukan dengan mempertimbangkan karakteristik kelerengan pada lokasi penelitian. 


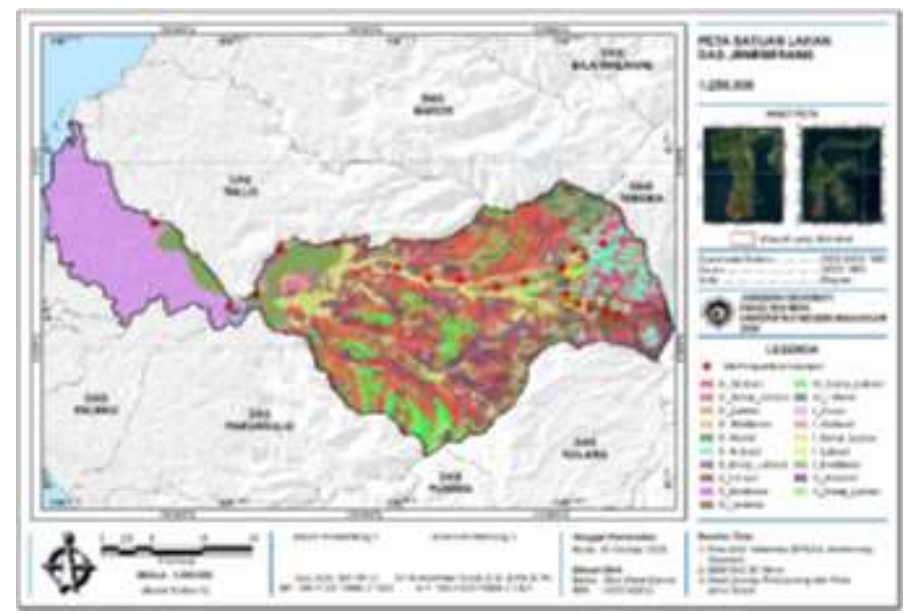

Gambar 2. Titik pengambilan sampel

\section{HASIL DAN PEMBAHASAN}

\section{Hasil}

\section{Jenis Batuan}

Faktor geologi dalam hal ini jenis batuan merupakan salah satu aspek yang mempengaruhi karakteristik suatu daerah. Jenis batuan yang paling mendominasi yaitu Tmc dengan luas wilayah $24.879 \mathrm{Ha}$ atau $31 \%$ dari luas total DAS Jeneberang. Tmc atau Batuan Gunungapi Camba adalah batuan sedimen laut berselingan dengan batuan gunungapi, batupasir tufa berselingan dengan tufa, batupasir, batulanau, dan batulempung konglomerat dan breksi gunungapi, dan setempat dengan batubara. Sedangkan jenis batuan yang paling sedikit yaitu Tpbc atau endapan Sumbat dengan luas wilayah $931 \mathrm{Ha}$ dengan persentase wilayah hanya $1 \%$.

Tabel 1. Luas DAS Jeneberang Berdasarkan Jenis Batuan

\begin{tabular}{cccc}
\hline $\begin{array}{c}\text { Jenis } \\
\text { Batuan }\end{array}$ & Keterangan & $\begin{array}{c}\text { Luas Wilayah } \\
(\text { Ha })\end{array}$ & $\begin{array}{c}\text { Persentase Luas } \\
\text { Wilayah }\end{array}$ \\
\hline Qac & Endapan Aluvium & 16658 & $21 \%$ \\
\hline Qlv & Batuan Gunungapi Lompobatang & 5704 & $7 \%$ \\
\hline Qlvb & Anggota Breksi & 10089 & $13 \%$ \\
\hline Qlvp & Hasil erupsi parasitik & 2763 & $4 \%$ \\
\hline Tmc & Formasi Camba & 24879 & $31 \%$ \\
\hline Tpbc & Endapan Sumbat & 931 & $1 \%$ \\
\hline Tpbl & Anggota Lava & 2161 & $3 \%$ \\
\hline Tpbv & Batuan Gunungapi Baturape & 15700 & $20 \%$ \\
\hline Jumlah & & $\mathbf{7 8 8 8 5}$ & $\mathbf{1 0 0 \%}$ \\
\hline
\end{tabular}

Peraturan Menteri Pekerjaan Umum menjelaskan bahwa batuan gunung api dan batuan sediment berukuran pasir dan campuran antara kerikil, pasir, dan lempung umumnya kurang kuat. Batuan tersebut akan mudah menjadi tanah apabila mengalami proses pelapukan dan umumnya rentan terhadap tanah longsor bila terdapat pada lereng yang terjal. 


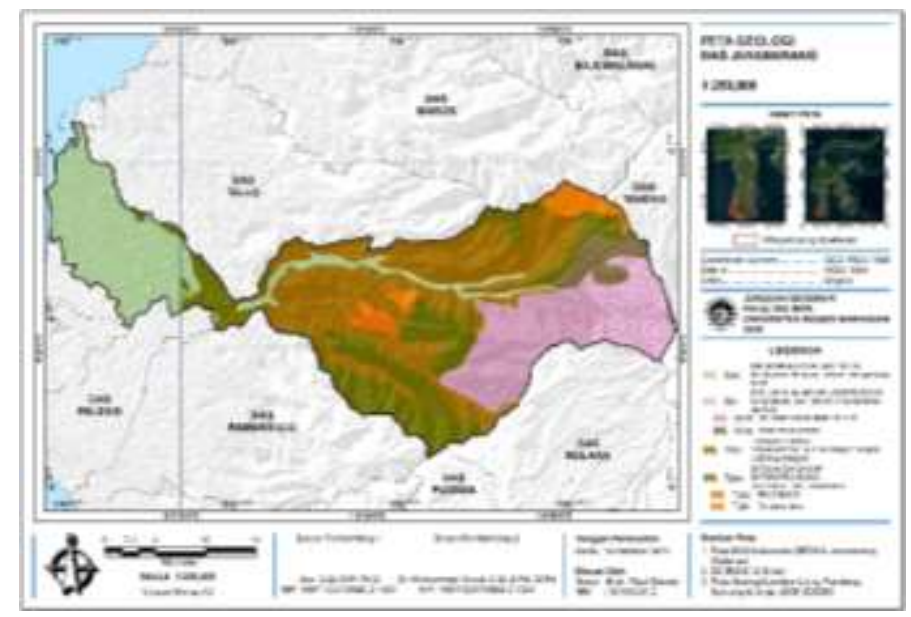

Gambar 3. Peta Geologi DAS Jeneberang

\section{Kemiringan Lereng}

Kelas kemiringan lereng yang paling luas adalah lereng kelas I $(0-8 \%)$ dengan luas wilayah $27.521 \mathrm{Ha}$ atau $35 \%$ dari luas total DAS Jeneberang. Adapun wilayah kemiringan lereng I mencakup kecamatan-kecamatan di hilir DAS Jeneberang yaitu Kecamatan Bajeng, Barombong, Bontomarannu, Galesong Utara, Mamajang, Mariso, Pallangga, Polombangkeng Utara, Rappocini, Somba Opu, Tamalate, dan Ujung Padang. Sedangkan kemiringan lereng yang paling sedikit adalah lereng kelas V (>45) dengan luas wilayah $454 \mathrm{Ha}(1 \%)$. Wilayah dengan kemiringan lereng V biasanya terdapat di hulu DAS Jeneberang yang mencakup Kecamatan Parigi dan Kecamatan Tinggimoncong.

Tabel 2. Luas DAS Jeneberang Berdasarkan Kemiringan Lereng

\begin{tabular}{cccc}
\hline $\begin{array}{c}\text { Kemiringan } \\
\text { Lereng }\end{array}$ & Keterangan & $\begin{array}{c}\text { Luas Wilayah } \\
(\text { Ha) }\end{array}$ & $\begin{array}{c}\text { Persentase Luas } \\
\text { Wilayah }\end{array}$ \\
\hline $0-8 \%$ & Datar & 27521 & $35 \%$ \\
\hline$>8-15 \%$ & Landai & 17457 & $22 \%$ \\
\hline$>15-25 \%$ & Miring & 23099 & $29 \%$ \\
\hline$>25-45 \%$ & Curam & 10354 & $13 \%$ \\
\hline$>45 \%$ & Sangat Curam & 454 & $1 \%$ \\
\hline Jumlah & & $\mathbf{7 8 8 8 5}$ & $\mathbf{1 0 0 \%}$ \\
\hline
\end{tabular}

Wilayah dengan lereng $25-45 \%$ (Curam) dan lereng >45\% (sangat curam) merupakan wilayah yang sangat berpotensi untuk terjadinya tanah longsor. Faktor kemiringan lahan sangat berpengaruh dalam proses tanah longsor, semakin tinggi dan semakin tegak lereng maka kemungkinan terjadinya longsor semakin tinggi. Hal tersebut berkaitan dengan kestabilan lereng, semakin curam lereng maka lereng akan mengalami tekanan beban yang lebih besar sehingga makin tidak stabil untuk menahan beban di atasnya dari pengaruh gravitasi bumi.

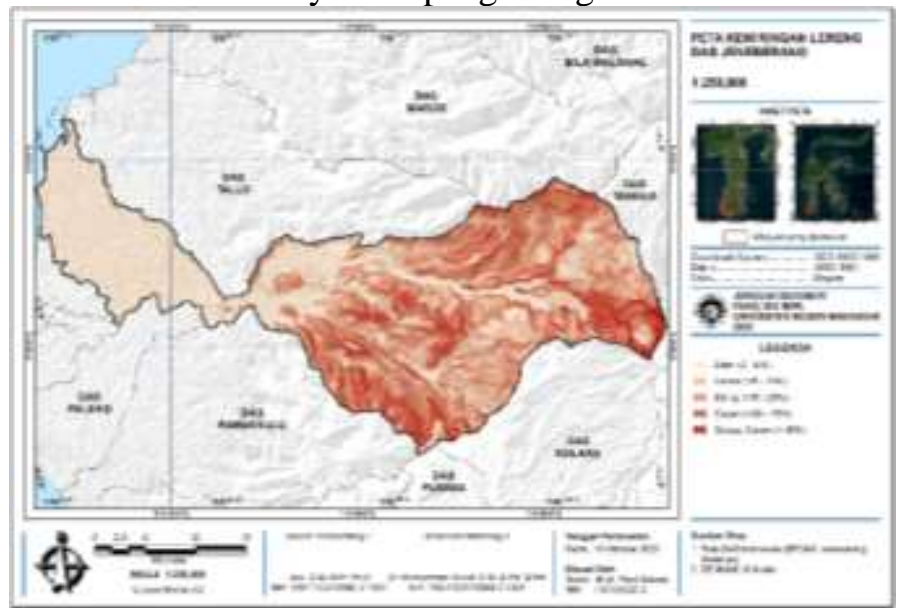

Gambar 4. Peta Kemiringan Lereng DAS Jeneberang 


\section{Curah Hujan}

Curah hujan merupakan faktor penentu selanjutnya, semakin tinggi curah hujan di suatu wilayah yang kemiringan lerengnya relatif terjal, maka dapat dipastikan wilayah tersebut berpotensi tinggi terjadi bencana longsor. Data carah hujan 10 tahun terakhir $(2009$ - 2018) diperoleh dari Balai Besar Wilayah Sungai Pompengan - Jeneberang dan UPT Jeneberang. Terdapat tujuh stasiun curah hujan yang tersebar dari hulu hingga hilir di sekitar DAS Jeneberang.

Tabel 3. Luas DAS Jeneberang Berdasarkan Curah Hujan

\begin{tabular}{cccc}
\hline Curah Hujan & Keterangan & $\begin{array}{c}\text { Luas Wilayah } \\
(\text { Ha) }\end{array}$ & $\begin{array}{c}\text { Persentase Luas } \\
\text { Wilayah }\end{array}$ \\
\hline$>2.000-3.000$ & Sedang & 9467 & $12 \%$ \\
\hline$>3.000-4000$ & Tinggi & 36647 & $46 \%$ \\
\hline$>4000$ & Sangat Tinggi & 32771 & $42 \%$ \\
\hline Jumlah & & $\mathbf{7 8 8 8 5}$ & $\mathbf{1 0 0 \%}$ \\
\hline
\end{tabular}

Wilayah dengan intensitas curah hujan tinggi (>3.000 - $4000 \mathrm{~mm} / \mathrm{tahun})$ merupakan wilayah yang paling luas yaitu $36.647 \mathrm{Ha}$ atau $46 \%$ dari total luas wilayah DAS Jeneberang, wilayah ini mendominasi setengah wilayah bagian selatan DAS Jenebrang dan setengah wilayahnya lagi bagian utara di dominasi oleh wilayah dengan intensitas curah hujan sangat tinggi ( $>4000 \mathrm{~mm} / \mathrm{tahun}$ ) dengan luas wilayah 32.771 atau $42 \%$ dari total luas wilayah DAS Jeneberang. Sedangkan wilayah dengan intensitas curah hujan sedang $(>2.000-3.000 \mathrm{~mm} / \mathrm{tahun})$ merupakan wilayah yang paling sedikit yaitu $9.467 \mathrm{Ha}$ atau $12 \%$ dari total luas wilayah DAS Jeneberang, wilayah ini mendominasi bagian hilir DAS Jeneberang.

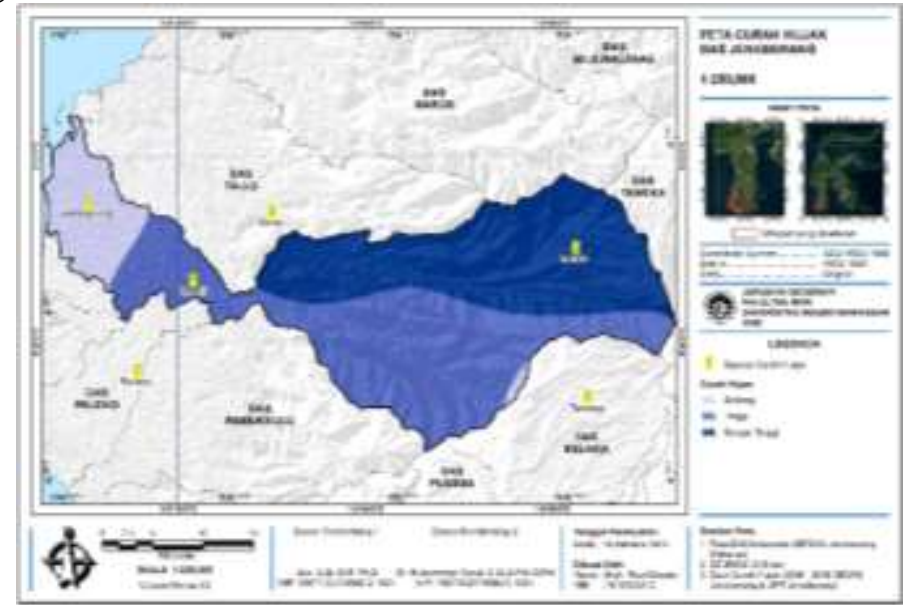

Gambar 5. Peta Curah Hujan DAS Jeneberang

\section{Zona Kerentanan Gerakan Tanah}

Kerentanan gerakan tanah merupakan salah satu faktor yang ikut andil dalam proses terjadinya tanah longsor. Hal ini berhubungan dengan letak suatu wilayah yang berada pada zona geologi aktif, dimana suatu wilayah yang berada pada zona geologi aktif memiliki frekuensi gerakan tanah yang tinggi. Gerakan tanah dapat memicu terjadinya longsor terutama pada daerah yang berada di lerenglereng curam.

Tabel 4. Luas DAS Jeneberang Berdasarkan Zona Kerentanan Gerakan Tanah

\begin{tabular}{|c|c|c|}
\hline $\begin{array}{c}\text { Zona Kerentanan Gerakan } \\
\text { Tanah }\end{array}$ & $\begin{array}{c}\text { Luas Wilayah } \\
\text { (Ha) }\end{array}$ & $\begin{array}{c}\text { Persentase Luas } \\
\text { Wilayah }\end{array}$ \\
\hline Sangat Rendah & 18559 & $24 \%$ \\
\hline Rendah & 22950 & $29 \%$ \\
\hline Menengah & 25921 & $32 \%$ \\
\hline Tinggi & 11455 & $15 \%$ \\
\hline Jumlah & 78885 & $100 \%$ \\
\hline
\end{tabular}


Zona gerakan tanah menengah merupakan wilayah yang paling luas dibandingkan dengan kelas lainnya, memiliki luas $25.921 \mathrm{Ha}$ atau $32 \%$ dari luas total DAS Jeneberang. Sedangkan, wilayah yang paling sedikit adalah wilayah dengan zona gerakan tanah tinggi yang memiliki luas $11.455 \mathrm{Ha}$ atau hanya $15 \%$ dari luas total DAS Jeneberang. Kedua wilayah ini sebagian besar meliputi dan tersebar di kecamatan Bungaya, Manuju, Parangloe, Parigi, dan Tinggimoncong.

Zona kerentanan gerakan tanah tinggi merupakan wilayah yang paling berpotensi terjadinya tanah longsor mengingat tingginya frekuensi gerakan tanah di wilayah tersebut. Sedangkan wilayah yang berada di luar zona menandakan wilayah tersebut tidak berada pada zona geologi aktif sehingga frekuensi gerakan tanah sangat jarang terjadi.

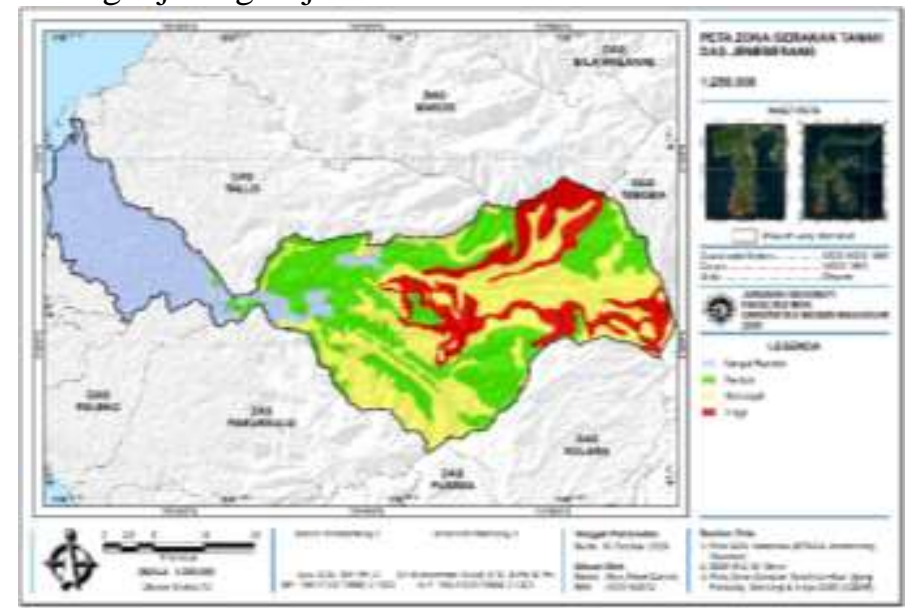

Gambar 6. Peta Zona Kerentanan Gerakan Tanah Sub DAS Jeneberang

\section{Tekstur Tanah}

Berdasarkan hasil uji laboratorium pada 19 sampel tanah lokasi penelitian diperoleh 5 jenis tekstur tanah yaitu lempung berdebu, lempung liat berpasir, lempung berpasir, pasir berlempung, dan pasir. Untuk membuat peta sebaran tekstur tanah, digunakan metode Kriging dengan menentukan bobot dari nilai sekitar yang terukur. Dengan kata lain, metode ini digunakan untuk mengestimasi nilai pada titik yang tidak tersampel berdasarkan informasi dari karakteristik nilai tersampel yang berada pada wilayah sekitarnya.

Tabel 5. Luas DAS Jeneberang Berdasarkan Tekstur Tanah

\begin{tabular}{ccc} 
Tekstur Tanah & $\begin{array}{c}\text { Luas Wilayah } \\
\text { (Ha) }\end{array}$ & $\begin{array}{c}\text { Persentase Luas } \\
\text { Wilayah }\end{array}$ \\
\hline Sangat Kasar (Pasir) & 16299 & $21 \%$ \\
\hline Kasar (Lempung berpasir, Pasir berlempung) & 34187 & $43 \%$ \\
\hline Sedang (Lempung liat berpasir) & 24377 & $31 \%$ \\
\hline Sangat Halus (Lempung berdebu) & 4022 & $5 \%$ \\
\hline Jumlah & $\mathbf{7 8 8 8 5}$ & $\mathbf{1 0 0 \%}$ \\
\hline
\end{tabular}

Wilayah dengan tekstur tanah kasar (Lempung berpasir, Pasir berlempung) adalah wilayah yang paling luas, dengan luas wilayah $34.187 \mathrm{Ha}$ atau $43 \%$ dari total luas DAS Jeneberang, kemudian tekstur tanah sedang (Lempung liat berpasir) mempunyai luas wilayah $24.377 \mathrm{Ha}(31 \%)$, tekstur tanah sangat kasar (Pasir) mempunyai luas wilayah 16.299 Ha (21\%), dan tekstur tanah sangat halus (Lempung berdebu) adalah wilayah yang memiliki luas yang paling sedikit yaitu $4.022 \mathrm{Ha}$ atau hanya $5 \%$ dari total luas DAS Jeneberang. 


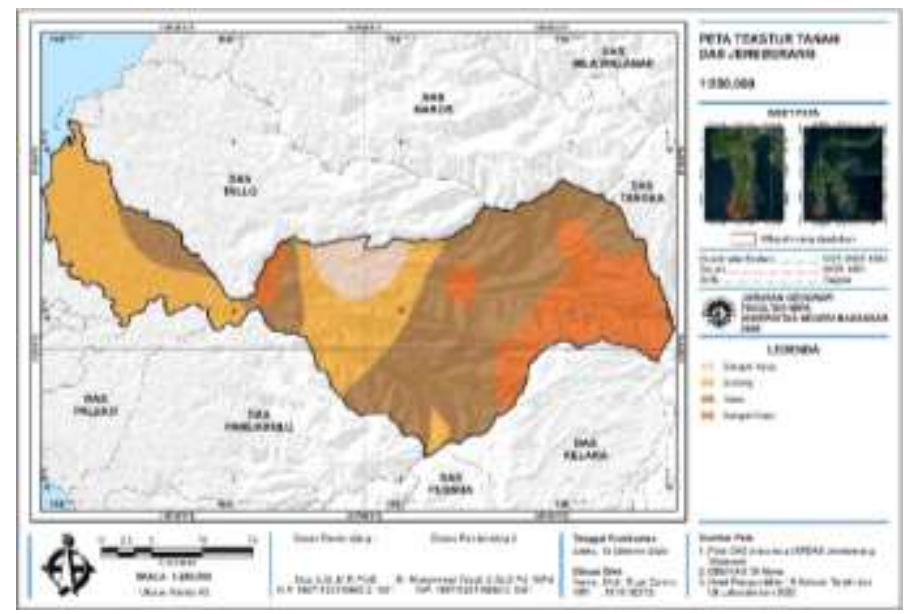

Gambar 7. Peta Tekstur Tanah DAS Jeneberang

\section{Tutupan Lahan}

Penutupan lahan sebagai faktor penyebab tanah longsor berkaitan dengan kestabilan lahan, kontrol terhadap kejenuhan air serta kekuatan ikatan partikel tanah. Tipe penutupan lahan memiliki kontribusi yang berbeda-beda tergantung pada sifat dan kondisi penutupan lahan tersebut seperti bentuknya berupa bangunan atau tanaman, jenis tanaman, sifat tanaman, luasan penutupan lahan serta lokasi dimana penutupan lahan itu berada (Rahmat, 2010).

Tabel 6. Luas DAS Jeneberang Berdasarkan Tutupan Lahan

\begin{tabular}{ccc}
\hline Tutupan Lahan & $\begin{array}{c}\text { Luas Wilayah } \\
(\text { Ha) }\end{array}$ & $\begin{array}{c}\text { Persentase Luas } \\
\text { Wilayah }\end{array}$ \\
\hline Badan Air & 2859 & $4 \%$ \\
\hline Belukar & 6258 & $8 \%$ \\
\hline Hutan & 13085 & $17 \%$ \\
\hline Permukiman & 3127 & $4 \%$ \\
\hline Pertambangan & 114 & $1 \%$ \\
\hline Pertanian Lahan Kering & 33262 & $40 \%$ \\
\hline Sawah & 19194 & $24 \%$ \\
\hline Tambak & 449 & $1 \%$ \\
\hline Tanah Terbuka & 537 & $1 \%$ \\
\hline Jumlah & $\mathbf{7 8 8 8 5}$ & $\mathbf{1 0 0 \%}$ \\
\hline
\end{tabular}

Tutupan lahan yang paling luas adalah pertanian lahan kering dengan luas wilayah $33.262 \mathrm{Ha}$ atau $40 \%$ dari total luas DAS Jeneberang. Daerah pertanian lahan kering merupakan areal yang diusahakan untuk budidaya tanaman pangan dan hortikultura dan berada pada areal lahan kering dataran rendah, perbukitan, maupun pegunungan. Sedangkan tutupan lahan yang paling sedikit adalah pertambangan, tambak \& tanah terbuka dengan luas masing-masing $114 \mathrm{Ha}, 449 \mathrm{Ha}$, dan $537 \mathrm{Ha}$ atau hanya $1 \%$ dari total luas DAS Jeneberang.

Lahan yang ditutupi hutan dan perkebunan relatif lebih bisa menjaga stabilitas lahan karena sistem perakaran yang dalam sehingga bisa menjaga kekompakan antar partikel tanah serta partikel tanah dengan batuan dasar dan bisa mengatur limpasan dan resapan air ketika hujan. Sedangkan tegalan dan sawah memiliki vegetasi yang tidak bisa menjaga stabilitas permukaan karena bersifat tergenang, serta memiliki sistem perakaran yang dangkal sehingga kurang menjaga kekompakan partikel tanah. Pada lahan dengan tipe penutupan lahan demikianlah tanah longsor seringkali terjadi. 


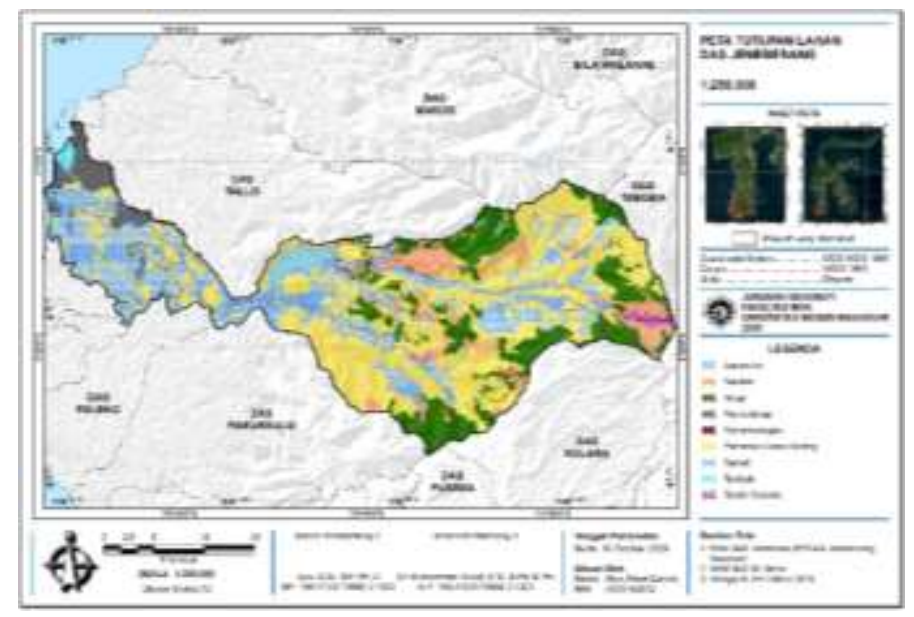

Gambar 8. Peta Tutupan Lahan DAS Jeneberang

\section{Analisis Tingkat Kerawanan Longsor DAS Jeneberang}

Untuk mengetahui sebaran daerah rawan longsor di DAS Jeneberang dapat dilakukan dengan menggunakan perangkat lunak ArcGIS 10.5 dengan melakukan analisis tumpang susun (Overlay) pada peta-peta tematik yang merupakan parameter fisik penentu daerah rawan longsor, yaitu Peta Jenis Batuan, Peta Curah Hujan, Peta Kemiringan Lereng, Peta Kerentanan Gerakan Tanah, Peta Tekstur Tanah dan Peta Tutupan Lahan. Penentuan daerah rawan longsor diperoleh dari pengolahan skor dan bobot dari masing-masing variabel sehingga akan menghasilkan nilai bobot baru yang merupakan nilai potensi rawan longsor setelah variabel-variabel tersebut ditumpang susunkan (Overlay).

Nilai skor total untuk menentukan tingkat daerah rawan longsor diperoleh melalui model pendugaan, sedangkan pemberian bobot untuk menentukan tingkat daerah rawan longsor disesuaikan dengan faktor terbesar atau faktor dominan penyebab terjadinya longsor. Menurut Balai Besar Litbang Sumberdaya Lahan Pertanian (2009) Geologi atau jenis batuan penyusun di suatu daerah merupakan faktor dominan penyebab terjadinya tanah longsor sehingga nilainya lebih tinggi dari variabel lainnya. Jenis batuan memiliki bobot sebesar $25 \%$ dari total pembobotan, sedangkan curah hujan dan kemiringan lereng memilki bobot yang sama yaitu 20\%, kerentanan gerakan tanah memiliki bobot $15 \%$ dan tekstur tanah dan tutupan lahan mempunyai bobot $10 \%$.

Model pendugaan yang digunakan untuk menganalisis potensi longsor di suatu wilayah mengacu pada Balai Besar Litbang Sumberdaya Lahan Pertanian (BBSDLP, 2009) dengan formula sebagai berikut:

$$
\begin{aligned}
\text { SKOR TOTAL }= & (25 \% \times \mathrm{JB})+(20 \% \times \mathrm{KL})+(20 \% \times \mathrm{CH})+ \\
& (15 \% \times \mathrm{KGT})+(10 \% \times \mathrm{TT})+(10 \% \times \mathrm{TL})
\end{aligned}
$$

Keterangan:

JB = Jenis Batuan

$\mathrm{KL} \quad=$ Kemiringan Lereng

$\mathrm{CH}=$ Curah Hujan

KGT = Kerentanan Gerakan Tanah

TT $=$ Tekstur Tanah

$\mathrm{TL} \quad=$ Tutupan Lahan

Adapun skor total di setiap satuan lahan untuk menentukan wilayah yang berpotensi longsor dapat dilihat pada tabel berikut ini: 
Tabel 7. Bobot, skor dan skor total setiap Variabel.

\begin{tabular}{|c|c|c|c|c|}
\hline Variabel & Klasifikasi & Bobot & Skor & $\begin{array}{l}\text { Skor } \\
\text { Total }\end{array}$ \\
\hline \multirow{2}{*}{$\begin{array}{l}\text { Jenis } \\
\text { Batuan }\end{array}$} & $\begin{array}{l}\text { Lahar, Lava, dan Breksi Vulkanik (Qlv, Qlvb, Qlvp, } \\
\text { Tpbc, Tpbl, Tpbv) }\end{array}$ & \multirow{2}{*}{$25 \%$} & 2 & 0,5 \\
\hline & $\begin{array}{l}\text { Batuan Endapan: Batu Lempung, Napal, Batu Pasir, } \\
\text { Lahar, Tufa dan Breksi (Qac, Tmc) }\end{array}$ & & 3 & 0,75 \\
\hline \multirow{5}{*}{$\begin{array}{l}\text { Kemiringan } \\
\text { Lereng }\end{array}$} & Datar $(0-8 \%)$ & \multirow{5}{*}{$20 \%$} & 1 & 0,20 \\
\hline & Landai $(>8-15 \%)$ & & 2 & 0,40 \\
\hline & Miring $(>15-25 \%)$ & & 3 & 0,60 \\
\hline & Curam $(>25-45 \%)$ & & 4 & 0,80 \\
\hline & Sangat Curam (> 45\%) & & 5 & 1,00 \\
\hline \multirow{3}{*}{$\begin{array}{l}\text { Curah } \\
\text { Hujan }\end{array}$} & Sedang $(>2.000-3.000 \mathrm{~mm} / \mathrm{thn})$ & \multirow{3}{*}{$20 \%$} & 3 & 0,60 \\
\hline & Tinggi $(>3.000-4000 \mathrm{~mm} / \mathrm{thn})$ & & 4 & 0,80 \\
\hline & Sangat Tinggi $(>4000 \mathrm{~mm} / \mathrm{thn})$ & & 5 & 1,00 \\
\hline \multirow{4}{*}{$\begin{array}{c}\text { Zona } \\
\text { Kerentanan } \\
\text { Gerakan } \\
\text { Tanah }\end{array}$} & Sangat Rendah & \multirow{4}{*}{$15 \%$} & 2 & 0,30 \\
\hline & Rendah & & 3 & 0,45 \\
\hline & Menengah & & 4 & 0,60 \\
\hline & Tinggi & & 5 & 0,75 \\
\hline \multirow{4}{*}{$\begin{array}{l}\text { Tekstur } \\
\text { Tanah }\end{array}$} & Sangat Halus & \multirow{4}{*}{$10 \%$} & 1 & 0,10 \\
\hline & Sedang & & 3 & 0,30 \\
\hline & Kasar & & 4 & 0,40 \\
\hline & Sangat Kasar & & 5 & 0,50 \\
\hline \multirow{5}{*}{$\begin{array}{c}\text { Tutupan } \\
\text { Lahan }\end{array}$} & Hutan, Badan Air, Tambak & \multirow{5}{*}{$10 \%$} & 1 & 0,10 \\
\hline & Pertanian Lahan Kering, Semak Belukar & & 2 & 0,20 \\
\hline & Sawah Irigasi & & 3 & 0,30 \\
\hline & Permukiman, Pertambangan & & 4 & 0,40 \\
\hline & Tanah Terbuka & & 5 & 0,50 \\
\hline
\end{tabular}

Dengan menggunakan 6 variabel penentu tingkat bahaya longsor tersebut, maka penentuan tingkat bahaya longsor di setiap satuan lahan di DAS Jeneberang dibagi menjadi tiga kelas kerawanan longsor yaitu: rendah, sedang dan tinggi dengan menggunakan rumus sebagai berikut:

$$
\text { Kelas Interval }=\frac{\text { Skor Total Tertinggi }- \text { Skor Total Terendah }}{\text { Jumlah Kelas }}
$$

Berdasarkan persamaan diatas, maka:

$$
\begin{aligned}
\text { Kelas Interval } & =\frac{4,25-2,00}{3} \\
& =0,75
\end{aligned}
$$

Dengan demikian maka interval kelas rawan longsor dapat disajikan pada tabel berikut ini:

Tabel 8. Klasifikasi Tingkat Rawan Bencana Longsor.

\begin{tabular}{ccc}
\hline Kelas & Kelas Interval & Tingkat Rawan Longsor \\
\hline I & $2,00-2,75$ & Rendah \\
\hline II & $2,76-3,50$ & Sedang \\
\hline III & $3,51-4,25$ & Tinggi \\
\hline
\end{tabular}

Sumber: BBSDLP (2009)

Berdasarkan hasil tumpang susun (overlay) dan analisis skor total pada beberapa parameter seperti peta jenis batuan, peta kemiringan lereng, peta curah hujan, peta kerentanan gerakan tanah, peta tekstur tanah dan peta tutupan lahan, DAS Jeneberang memiliki 3 tingkat kerawanan longsor yaitu: wilayah dengan tingkat kerawanan rendah, sedang dan tinggi. 


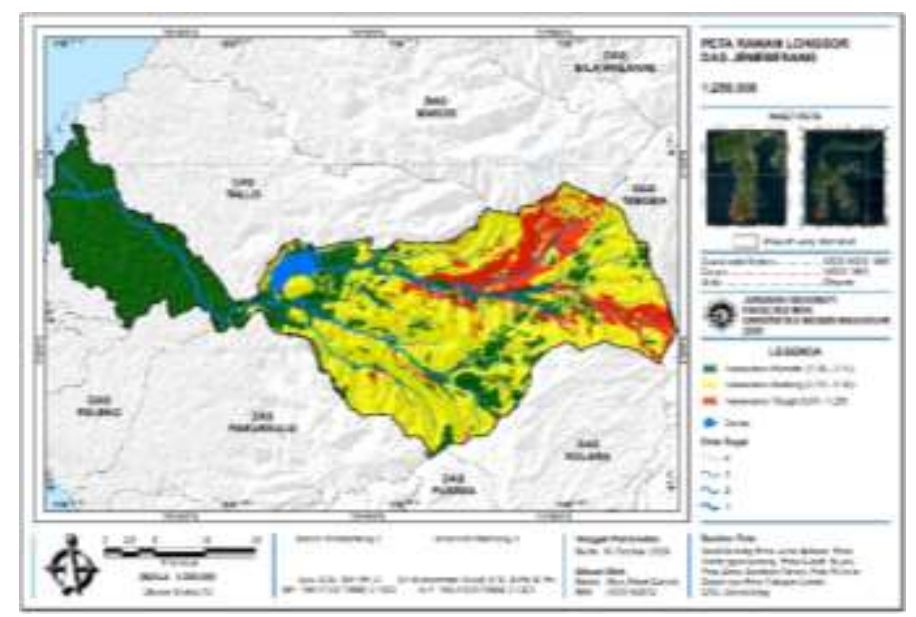

Gambar 9. Peta Kerawanan Longsor DAS Jeneberang

Tingkat kerawanan longsor DAS Jeneberang didominasi oleh wilayah dengan tingkat kerawanan sedang seluas $38.827 \mathrm{Ha}$ atau $49 \%$ dari total luas DAS Jeneberang. Kemudian wilayah dengan tingkat kerawanan rendah memiliki luas $30.771 \mathrm{Ha}(39 \%)$ dan wilayah yang paling sedikit adalah wilayah dengan tingkat kerawanan tinggi seluas 9.287 Ha atau hanya 12\% dari total luas DAS Jeneberang.

\section{Pembahasan \\ 1. Sebaran Tingkat Kerawanan Longsor DAS Jeneberang \\ a. Tingkat Kerawanan Rendah}

Daerah dengan tingkat kerawanan rendah adalah daerah yang memiliki parameter penentu bahaya longsor dengan skor total yang rendah (Interval 2,00-2,75). Dalam penelitian ini, daerah dengan tingkat bahaya longsor rendah memiliki luas $30771 \mathrm{Ha}$, atau 39\% dari luas total DAS Jeneberang. Karakteristik satuan lahan yang memiliki tingkat kerawanan longsor rendah didominasi oleh batuan endapan dan yang terdapat pada hilir DAS Jeneberang yang lereng-lereng dengan kemiringan 0-8\% sehingga bisa dikatakan jika daerah dengan kemiringan lereng datar sangat kecil kemungkinan untuk terjadi longsor lahan, curah hujan di hilir DAS Jeneberang yang relatif lebih rendah dan di dominasi oleh zona dengan kerentanan tanah sangat rendah, untuk tanahnya sendiri didominasi oleh tanah bertekstur sedang dan memiliki tutupan lahan yang kebanyakan daerah persawahan. Variabel-variabel tersebut memiliki skor total yang rendah dibandingkan satuan lahan di daerah lain sehingga juga mempunyai pengaruh yang kecil terhadap timbulnya bencana longsor di DAS Jeneberang.

\section{b. Tingkat Kerawanan Sedang}

Daerah dengan tingkat kerawanan sedang adalah daerah yang memiliki parameter penentu bahaya longsor dengan skor yang total sedang (Interval 2,76-3,50). Dalam penelitian ini, daerah dengan tingkat bahaya longsor sedang memiliki luas $38827 \mathrm{Ha}$, atau $49 \%$ dari luas total DAS Jeneberang. Karakteristik satuan lahan yang memiliki tingkat kerawanan longsor sedang bisa terjadi dikarenakan setiap variabel saling mempengaruhi dengan variabel lainnya. Daerah dengan tingkat kerawanan sedang di dominasi oleh batuan lahar, lava, dan breksi vulkanik yang tersebar sepanjang DAS Jeneberang dimana wilayah tersebut miliki wilayah dengan lereng-lereng landai hingga curam (8-45\%), curah hujan yang bervariasi yaitu daerah dengan curah tinggi terdapat disebelah Selatan DAS Jeneberang dan curah hujan yang sangat tinggi terdapat disebelah Utara DAS Jeneberang, zona kerentanan gerakan tanah di daerah kerawanan longsor sedang juga bervariasi, yaitu daerah dengan zona kerentanan gerakan tanah rendah, sedang dan tinggi, untuk tanahnya sendiri, tanah yang bertekstur sangat halus, sedang, kasar dan sangat kasar tersebar di sepanjang DAS Jeneberang, dan tutupan lahan untuk daerah dengan tingkat kerawanan longsor sedang cukup bervariasi, mulai dari pertanian lahan kering, sawah, belukar dan hutan. Variabel-variabel tersebut memiliki skor total sedang dibandingkan satuan lahan di daerah lain sehingga juga mempunyai pengaruh sedang terhadap timbulnya bencana longsor di DAS Jeneberang. 


\section{c. Tingkat Kerawanan Tinggi}

Daerah dengan tingkat kerawanan tinggi adalah daerah yang memiliki parameter penentu bahaya longsor dengan skor yang total tinggi (Interval 3,51-4,25). Dalam penelitian ini, daerah dengan tingkat bahaya longsor tinggi memiliki luas $9287 \mathrm{Ha}$, atau $12 \%$ dari luas total DAS Jeneberang. Karakteristik satuan lahan yang memiliki tingkat kerawanan longsor tinggi didominasi oleh batuan lahar, lava, dan breksi vulkanik di hulu DAS Jeneberang dimana wilayah tersebut memiliki wilayah dengan lereng-lereng curam hingga sangat curam (25-45\% bahkan lebih), curah hujan yang tinggi di sebelah utara DAS Jeneberang, daerah ini juga di memiliki zona dengan kerentanan tanah sedang hingga tinggi, untuk tanahnya sendiri didominasi oleh tanah bertekstur kasar hingga sangat kasar, tutupan lahan kebanyakan pertanian lahan kering, belukar dan tanah kosong. Variabel-variabel tersebut memiliki skor total yang tinggi dibandingkan satuan lahan di daerah lain sehingga juga mempunyai pengaruh yang besar terhadap timbulnya bencana longsor di DAS Jeneberang.

\section{Mitigasi Bencana Daerah Rawan Longsor}

Upaya mitigasi bencana longsor sangat penting terutama untuk wilayah dengan tingkat kerawanan longsor tinggi yang memiliki persebaran di hulu DAS Jeneberang yaitu di Kecamatan Tinggimoncong, Parigi dan beberapa daerah di Kecamatan Parangloe dan Manuju. Inilah sebabnya perlu dilakukan upaya dan strategi penanggulangan tanah longsor antara lain adalah dengan:

a. Hindari Membuat Sawah di atas Lereng, hal ini hanya akan semakin meningkatkan potensi terjadinya tanah longsor.

b. Tidak membangun rumah di bawah tebing, karena mendirikan bangunan di bawah tebing memiliki ancaman besar terkena bencana tanah longsor.

c. Hindari menebang pohon di sekitar lereng, pohon yang berada di sekitar lereng menjadi pencegah terjadinya tanah longsor karena akar-akar dari pohon-pohon tersebut menyebar dan saling bersinggungan sehingga bisa membantu tanah tidak mudah longsor karena akan menjadi penahan tanah.

d. Pembuatan bangunan penahan agar mengurangi terjadi pergerakan tanah penyebab tanah longsor.

e. Warning system atau teknologi peringatan bencana longsor dengan menciptakan alat-alat pendeteksi pergerakan tanah yang berisiko akan longsor di daerah-daerah longsor.

Upaya penanggulangan tanah longsor seperti halnya banjir, harus terintegrasi antara tindakan masyarakat yang bermukim di area rawan longsor dengan pemerintah setempat. (BPBD, 2019)

\section{SIMPULAN}

Wilayah DAS Jeneberang di dominasi oleh daerah dengan tingkat kerawanan longsor sedang, dengan luas $38827 \mathrm{Ha} \mathrm{(49 \% )}$ ) atau hampir setengah dari luas total DAS Jeneberang. Berdasarkan hasil pendugaan kerawanan longsor di DAS Jeneberang, diperoleh tiga tingkat kerawanan longsor yaitu: Tingkat kerawanan rendah dengan luas $30771 \mathrm{Ha}$ (39\%) memiliki persebaran di Kecamatan Bontomaranu, Palangga, Bajeng Barombong, Tamalate, dan lain-lain, Tingkat kerawanan sedang dengan luas 38827 Ha (49\%) memiliki persebaran di Kecamatan Parangloe, Manuju, Bungaya, Tinggimoncong dan Parigi. Dan tingkat kerawanan tinggi dengan luas 9287 Ha (12\%) memiliki persebaran di Kecamatan Tinggimoncong dan Parigi.

\section{DAFTAR PUSTAKA}

Arsyad, S. 2010. Konservasi Tanah \& Air. Bogor: IPB Press.

Badan Nasional Penanggulangan Bencana (BNPB). 2013. Indeks Risiko Bencana Indonesia (IRBI). 
Balai Besar Litbang Sumberdaya Lahan Pertanian (BBSDLP). 2009. Identifikasi dan Karakterisasi Lahan Rawan longsor dan Rawan Erosi di Dataran Tinggi untuk Mendukung Keberlanjutan Pengelolaan Sumberdaya Lahan Pertanian. Laporan Tengah Tahun, DIPA 2009. Bogor: Balai Besar Litbang Sumberdaya Lahan Pertanian.

Balai Besar Wilayah Sungai (BBWS) Pompengan Jeneberang. 2016. Wilayah Kerja. http://sda.pu.go.id/balai/bbwspompenganjeneberang. (10 Oktober 2020)

BPDAS Jeneberang Walanae, 2010, Review Karakteristik DAS Jeneberang Tahun 2010, Balai Pengelolaan Daerah Aliran Sungai Jeneberang Walanae, Makassar.

Direktorat Vulkanologi dan Mitigasi Bencana Geologi. 2005. Manajemen Bencana Tanah Longsor.

Effendi, A. D. 2008. Identifikasi Kejadian Longsor Dan Penentuan Faktor-Faktor Utama Penyebabnya Di Kecamatan Babakan Madang Kabupaten Bogor. Skripsi. Fakultas Kehutanan IPB.

Fahmi, M. C. 2015. PENGELOLAAN DAERAH ALIRAN SUNGAI JENEBERANG KOTA MAKASSAR-SULAWESI SELATAN.

Hardiyatmo, H. C. 2012. TANAH LONGSOR \& EROSI - Kejadian dan Penanganan. Yogyakarta: Gadjah Mada University Press.

Hermon, D. D. 2015. Geografi Bencana Alam. Jakarta, Indonesia: PT RajaGrafindo Persada.

Mubekti dan Alsanah F. 2008. Mitigasi Daerah Rawan Tanah Longsor Menggunakan Teknik Pemodelan SIG. Jurnal Teknik Lingkungan. Jakarta.

Nasiah dan Invanni, I. 2016. MITIGASI BENCANA (Disaster Mitigation). Makassar, Sulawesi Selatan, Indonesia: Aguscorp.

Peraturan Menteri Pekerjaan Umum Tahun 2007 Tentang Pedoman Penataan Ruang Kawasan Rawan Bencana Longsor 